CIVIL AND ENVIRONMENTAL ENGINEERING REPORTS

E-ISSN 2450-8594

CEER 2020; 30 (4): 0090-0101

DOI: $10.2478 /$ ceer-2020-0052

Original Research Article

\title{
DIAGNOSIS OF THE TECHNICAL CONDITION OF HISTORIC TENEMENT HOUSES AS THE FIRST STAGE OF REVITALISATION OF THE CITY
}

\author{
Beata NOWOGOŃSKA ${ }^{1}$ \\ University of Zielona Gora, Zielona Góra, Poland
}

\begin{abstract}
Revitalisation of degraded downtown areas is a problem for many cities and towns in Europe. All spatial, economic and social changes result from the expectations of residents together with technical needs. The scope of revitalisation activities results from the diagnosis of the technical condition of the degraded part of the city. The article presents a sample assessment of the technical condition of a tenement house in Kożuchów located within a downtown complex covered by revitalisation plans.
\end{abstract}

Keywords: revitalisation, technical condition assessment, technical wear degree, historic buildings

\section{INTRODUCTION}

Revitalisation covers a wide range of activities related to the processes of spatial, economic and social transformation of a degraded part of the city [10, 12-16]. The first stage of revitalisation is the study of local needs related to both residents' expectations and architectural and construction problems. In the case of revitalisation of historic tenement houses, the scope of activities largely depends on the state of preservation of the historic place [10]. All actions should be

\footnotetext{
1 Corresponding author: University of Zielona Góra, Faculty of Building, Architecture and Environmental Engineering, Z. Szafrana st 1, 65-516 Zielona Góra, Poland, e-mail: b.nowogonska@ib.uz.zgora.pl
} 
preceded by a diagnosis of the technical condition of buildings, taking into account historical changes in building development [5-9, 11-14]. Diagnostics of individual buildings will allow determining the scale of needs in the revitalisation programme $[1-3,5-7]$.

\section{CHARACTERISTICS OF CUBATURE BUILDINGS IN THE KOŻUCHÓW OLD TOWN}

Kożuchów is one of the oldest cities in the Central Nadodrze region. In addition to the defensive walls, castle, numerous towers and bastilles, the Old Town also has many other valuable relics of the past. Within the fortifications, a group of historic tenement houses, located in a thirteenth-century urban layout, has survived to this day.

The complex of historic tenement houses has over 270 objects. The preserved buildings come from the period from the 16th to the beginning of the 20th century. Located on a harmonious, medieval layout of plots and streets, they are characterised by traditional form and scale. A significant group of tenement houses is founded on gothic foundations and their old layout of two or three storeys has been preserved. Renaissance portals have survived on some facades [4].

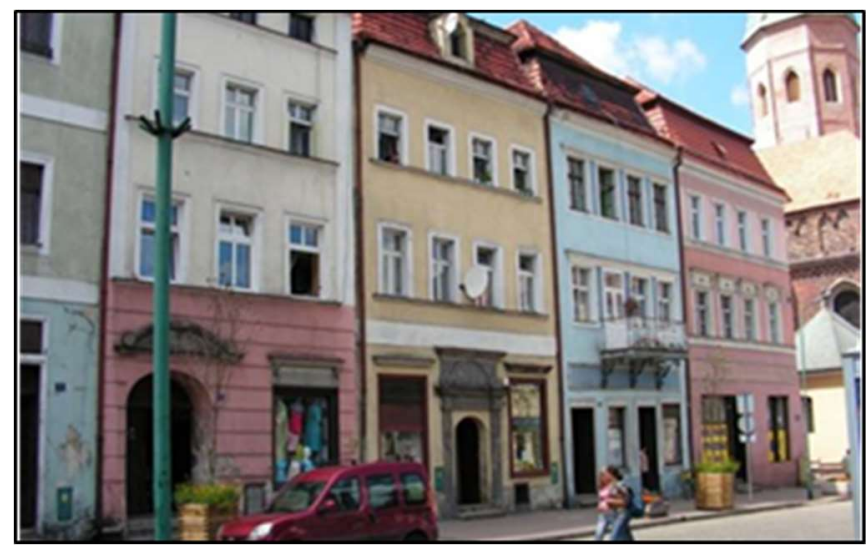

Fig. 1. Buildings in the Old Town complex in Kożuchów

Most of the buildings are three-bay, tenements are built on a plan of an elongated rectangle. At the ground floor level there is a passage to the yard. In the second bay there is a staircase, in the front bay there are store or service premises, in the rear there is a large room called the back chamber. The ceiling is made of cross or barrel vaults or a wooden ceiling.

These facilities require numerous treatments: renovation, elevation restoration, modernisation, extension, superstructure. An example is the eighteenth-century 
tenement house located at 71 Maja Street. 1 Maja Street connected the southwest corner of the market square with one of the four gates to the Old Town - the Żagańska Gate.

\section{CASE STUDY - TENEMENT HOUSE 71 MAJA STREET}

The tenement house consists of an older part A, with a basement, and part B, without a basement, erected in the second phase. Originally, the building served a service and residential function, currently due to its poor technical condition, the building is not in use. The building is founded on a plan of an elongated rectangle, located in a high-density development. The object is built in traditional technology, transverse structural layout. The building has two floors with a usable attic, covered with a pitched roof.

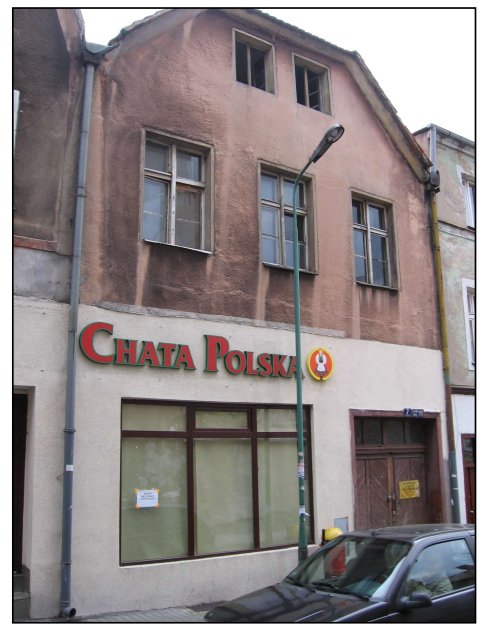

Fig. 2. Kożuchów 71 Maja Street. North elevation

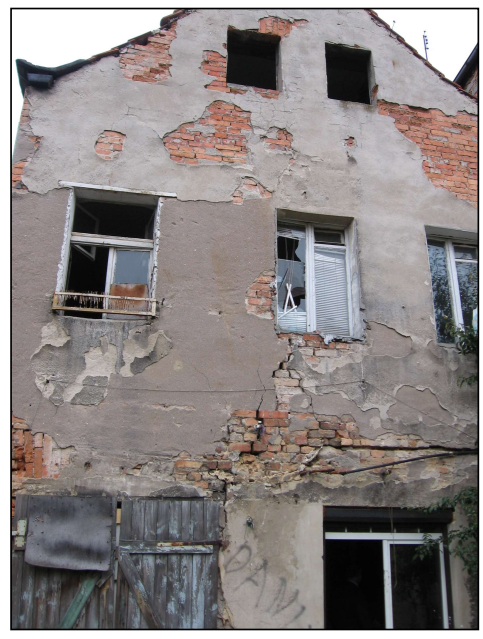

Fig. 3. South elevation. Numerous cracks and defects in the wall structure

The building's foundations (in part A) were made as strip foundations of $40 \mathrm{x} 60$ $\mathrm{cm}$ cross-section of erratic stone on lime mortar. Strip foundation depth about 60 $\mathrm{cm}$ below the level of the basement floor.

The foundations have surface moisture from groundwater, the mortar is partly washed out, the brickwork loose in some places. The foundation under the southern wall (in part B) is in the worst technical condition. During the analysis of scratches and cracks in the outer wall, it was found that the reason for these deformations is the foundation settlement in the south-west corner, caused by soil 
and water changes and technical wear of the foundation (loss of strength and rigidity of the strip foundation). There is no vertical or horizontal insulation.

The basement walls are made of erratic stone with lime mortar, the windows are framed with brick, the diameter of the stone is $10-30 \mathrm{~cm}$. Northern wall thickness (street side) $110 \mathrm{~cm}$. The wall is not plastered.

The walls of the ground floor in part A (older part, with basement) are made of solid bricks with dimensions $28 \times 14$ × $9 \mathrm{~cm}$ with lime and clay mortar. The walls of the ground floor in part B made of $25 \times 12 \times 6$ solid bricks with lime mortar. The attic walls are made of $25 \times 12 \times 6$ solid bricks with cement and lime mortar. The wall thicknesses on the ground floor vary, the northern wall $100 \mathrm{~cm}$ thick, southern wall $65 \mathrm{~cm}$ thick, western wall $28 \mathrm{~cm}$ thick, in the upper part it widens in the form of cantilever arcades reaching $40 \mathrm{~cm}$.

Wall thicknesses on the upper floor also vary, the northern wall $65 \mathrm{~cm}$ thick, southern wall $65 \mathrm{~cm}$ thick, western wall $28 \mathrm{~cm}$ thick, in the upper part it widens in the form of cantilever arcades reaching $40 \mathrm{~cm}$. In the attic, the northern outer wall is $40 \mathrm{~cm}$ thick, southern wall $35 \mathrm{~cm}$ thick.

The eastern wall in Part A was originally a wall separating two tenements. Currently, this wall has been removed and replaced with a joist based on pillars. In this way, a commercial room was created, occupying partly tenement house No. 5 and partly tenement house No. 7 .

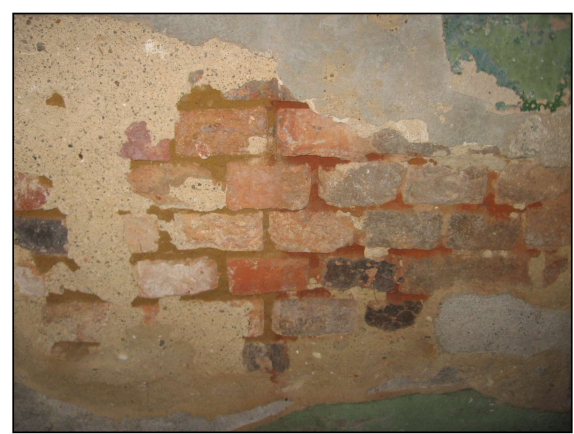

Fig. 4. Part of the western wall of the ground floor. Walls made of solid brick

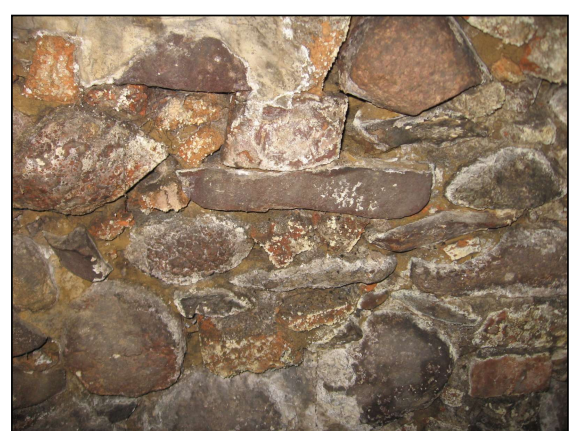

Fig. 5. Part of the stone wall of the basement. Wall salting and moisture

A diagonal structural crack is visible on the southern wall. The crack opening reaches up to $25 \mathrm{~mm}$. The crack runs near the south-west corner, runs from the foundations to the upper floor level. The crack reaches throughout the entire thickness of the wall. It is also visible inside the building. In addition, a horizontal crack between the ceiling above the ground floor and the southern wall is visible from the inside. Cracks between the ceiling and the wall indicate that the wall is deflecting from the vertical towards the outside. 
On the western wall of the upper floor, there is a diagonal crack running from the corner to the centre of the room and a vertical crack in the south-west corner.

There is a vertical crack between the gable (northern wall) and longitudinal (eastern and western) walls, indicating a deviation from the vertical of the wall towards the outside. The crack opening reaches $5 \mathrm{~mm}$, at the top it increases.

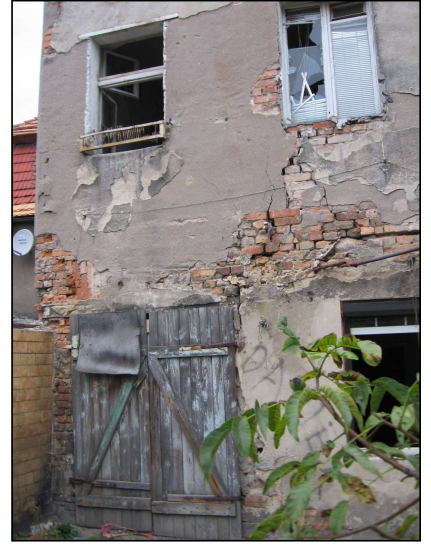

Fig. 6. Part of the southern elevation. Crack near the south-west corner

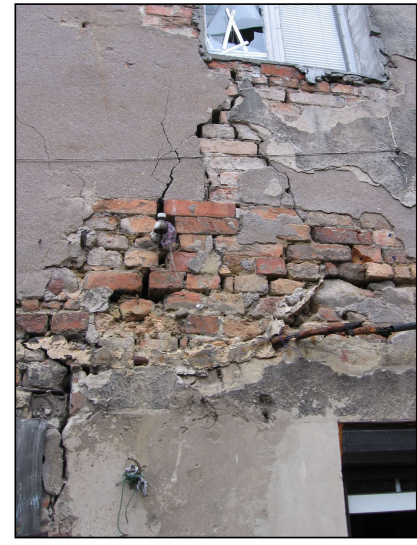

Fig. 7. Part of the southern elevation. Loose brickwork, defects in the joint

There are defects in the basement wall joints. The walls are very wet. From the inside, much efflorescence, severe salting and discolouration is visible.

The southern wall of the ground floor is very wet, moisture reaches 1.2-1.3 m, the other walls of the ground floor - moderately wet. The eastern wall on the upper floor is very wet from above due to leakage of the valley between the eaves of buildings No. 5 and 7.

The internal walls in part A (older part, with basement) are made of fired, solid bricks, $28 \times 14 \times 9 \mathrm{~cm}$, with clay and lime mortar, they are plastered on both sides. Wall thicknesses vary, from $9 \mathrm{~cm}$ (1/2 brick with plasters) to $30 \mathrm{~cm}$ (1 brick with plasters). There are no scratches or cracks in the internal walls.

The basements are covered with a brick barrel vault, $28 \mathrm{~cm}$ thick, vault height $\mathrm{f}=250 \mathrm{~cm}$. Above the ground floor, there is a wooden ceiling with sound boarding, ceiling beams of $18 \times 22 \mathrm{~cm}$ cross-section, spaced every $90-100 \mathrm{~cm}$.

The ceiling above the upper floor is wooden, $16 \times 22 \mathrm{~cm}$ ceiling beams spaced every $120-150 \mathrm{~cm}$. In the ceiling above the upper floor, the ends of beams based on the eastern wall are very wet. In the central part of the building, in the ceiling above the ground floor and upper floor, beams are corroded as a result of leakage of the sewage system. 


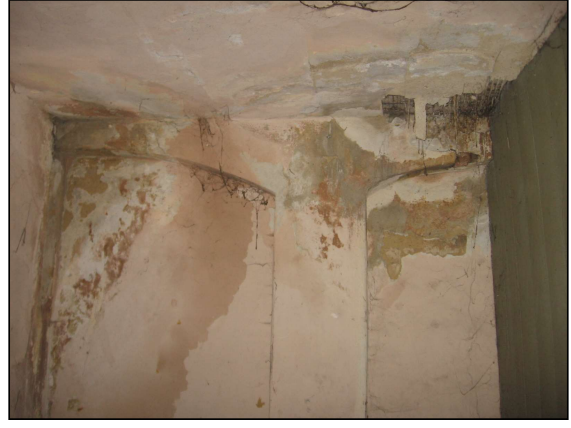

Fig. 8. Part of the eastern wall on the upper floor. Very damp wall and ceiling. Visible mould

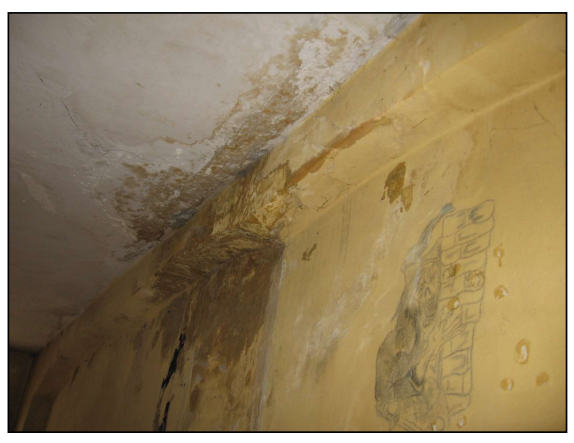

Fig. 9. Part of the eastern wall on the upper floor. Strong moisture of the wall and ceiling due to leakage of the valley

Taking into account the surveyed state of damage, it was found that the technical condition of wooden ceiling beams and other ceiling elements prevents the object from being operated in part B. Due to excessive deflection, significant biological corrosion of the ceiling beams (especially in the central part in the so-called wet rooms), and the high wear of the filling, it is suggested that ceilings should be replaced throughout the building.

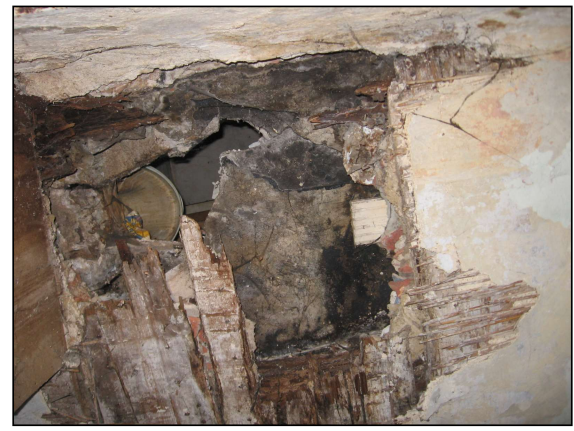

Fig. 10. Section of the ceiling above the ground floor. Missing part of the ceiling, other beams corroded

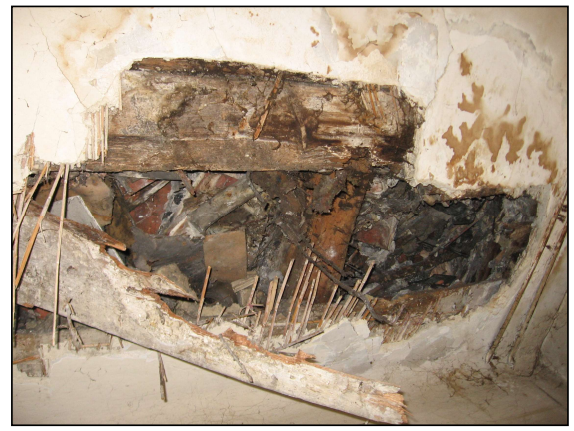

Fig. 11. Section of the ceiling above the ground floor. Moisture of ceiling beams, defects in the ceiling fillings

The stairs between the basement and the ground floor are brick, double, winder stairs. The stairs between the ground floor and the upper floor are wooden, notchboard, two-flight stairs, cross-section of the notchboard $7 \times 25 \mathrm{~cm}$, treadboard $3 \mathrm{~cm}$ thick. The stairs between the upper floor and the attic are wooden, notchboard, winder stairs. 
The roof is of a wooden structure, covered with double lapped plain tiles, no thermal insulation. A collar beam truss with two pine stool walls. Cross-sections of the roof truss elements are varied, e.g., rafters with $10 \times 20,14 \times 16$ cm crosssections, columns $-16 \times 22,18 \times 20 \mathrm{~cm}$, collar beam $18 \times 14 \mathrm{~cm}$, purlin $16 \times 14$ $\mathrm{cm}$, struts $12 \times 14 \mathrm{~cm}$, wall plate $20 \times 12 \mathrm{~cm}$. The truss structure is made of secondary elements, due to which the cross-sections of the elements are weakened.

Locally, there are biological infestations (of knocker), deflections and strong moisture of elements.

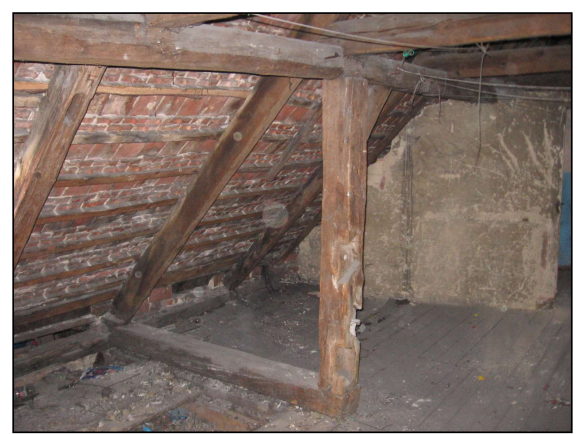

Fig. 12. Numerous defects in the construction of the truss. Purlins and rafters strongly bent

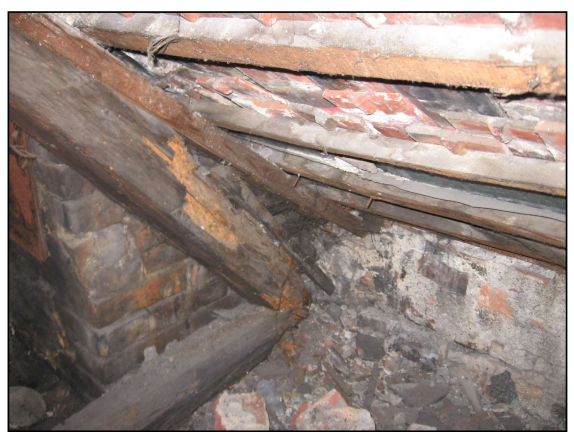

Fig. 13. Wet knee wall. The rafter ends are corroded, no wall plates, bent battens

Numerous defects in the truss structure are also visible. Some of them are caused by the removal of some structural elements during numerous roof modernisations, others have undergone significant biological corrosion. The ends of truss beams, rafter heads and wall plates are in the worst condition. Large distances between the rafters caused bends or breaks of battens under the tiles. Knee walls approx. $30 \mathrm{~cm}$ high are very wet, wall plates corroded, locally, there are no wall plates, rafters are based directly on the wall.

The building is not heated. There are negligible remains of equipment and heating system. The electrical installation is destroyed, the equipment is damaged, lighting points have provisional connections and they pose a risk of electric shock. In the building, there are negligible remains of a water and sewage system.

The building was divided into integrated elements, and detailed inspection was conducted for each of them. The assessment of the technical condition of individual building elements was made on the basis of visual inspections, control opencasts and checking measurements. 
The weighted average building wear level is $69.77 \%$. The result of the technical condition assessment shows the need for a comprehensive renovation of the building.

\section{ANALYSIS OF DEFORMATION OF MASONRY STRUCTURES}

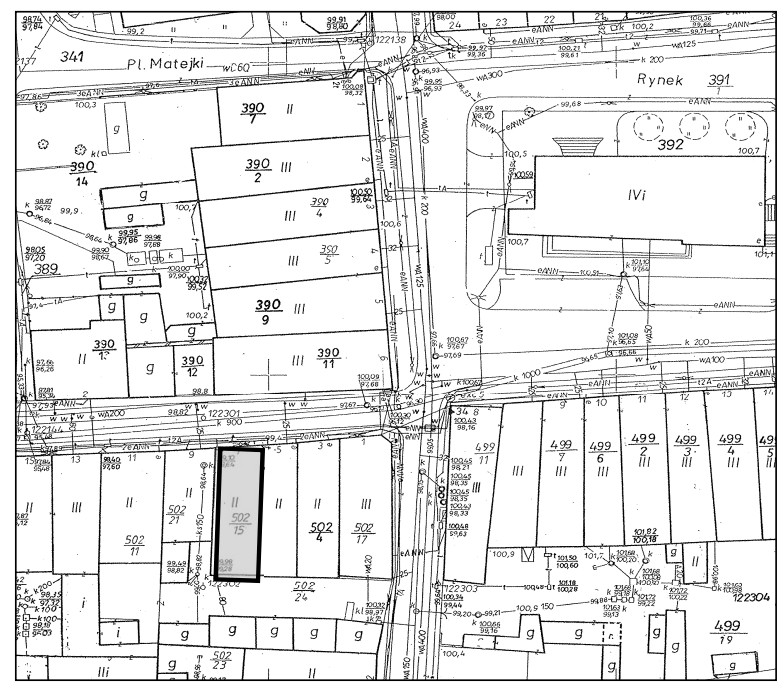

Fig. 14. Site plan

Alarming deformations of the building occur in its southern part. Structural scratches, numerous cracks are associated with foundation settlement in the southwest corner. This corner is not covered by high-density development (according to Fig. 14).

There has been a loss of strength and stiffness of the strip foundation in this part of the building, and this results in changes in the geometry of the southwest corner. During the site visit, measurements of gable wall deviations were made. Deviations from the wall vertical to a height of $5.0 \mathrm{~m}$ were measured.

The largest deviation values were recorded in the south-west corner of the southern wall amounting to $52 \mathrm{~mm}$, other deviations are within $30-40 \mathrm{~mm}$ for the southern wall, 10-20 $\mathrm{mm}$ for the northern wall (Fig. 15). Deviations are directed outside the building. 


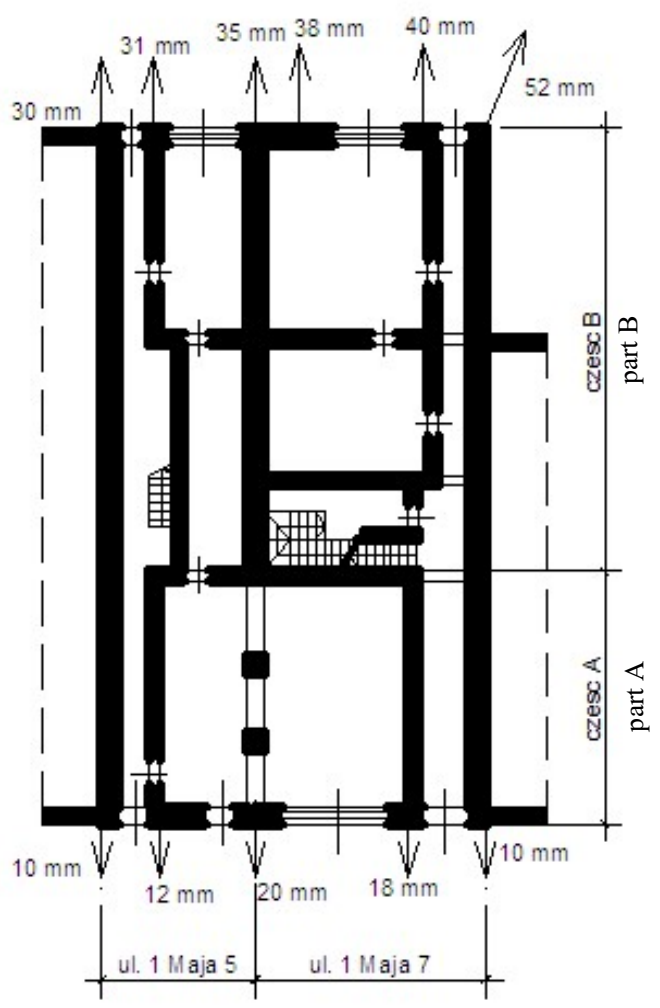

Fig. 15. The deviations from the vertical of the gable walls

\section{PROPOSALS AND RECOMMENDATIONS}

Based on the results of the analysis of safety of use, which covered all structural elements of the building, recommendations were developed for the scope of required and necessary works.

Required (immediate) works:

- foundation - from the south, expose, strengthen, and support the corner,

- walls - steel ties should be made at the ceiling level above the ground floor (according to Fig. 16), rebuild the part of the southern wall with cracks;

- ceilings - replacement in the central part of the building.

Necessary works:

- replacement of the roof covering, 
- reinforcement or replacement of the roof truss structure, a tie beam should be installed during works,

- replacement of other wooden ceilings,

- impregnation of all wooden elements present in the building,

- drying and desalting of walls,

- drying and desalting of brick vaults,

- replacement of wooden stairs,

- brick stairs maintenance,

- replacement of the lintel above the gate in the southern wall,

- replacement of partition walls,

- replacement of windows and doors,

- installation of central heating, water, sewage and electrical systems,

- replacement of floors,

- replacement of flashings, gutters and downpipes,

- repairing and supplementing internal plasters,

- supplementing external plaster defects.

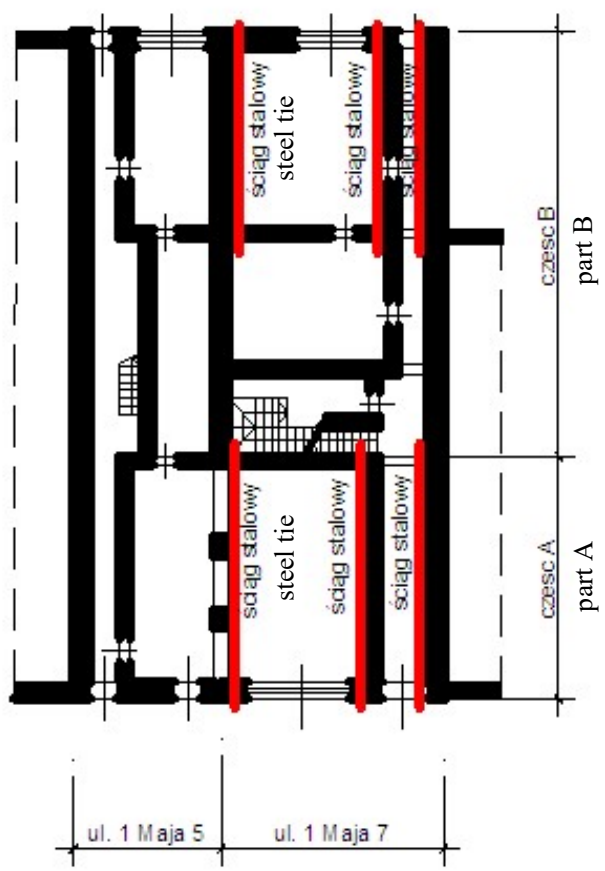

Fig. 16. Arrangement of the proposed bracing of gable walls 
Safe use and elimination of the causes of scratches and cracks can be ensured by a security system consisting in stopping the movement of foundations by exposing and strengthening the string foundation under the southern wall and in the southwest corner. Vertical and horizontal insulation should be made.

The southern and northern walls should be connected with anchors with longitudinal walls, cracks up to $4 \mathrm{~mm}$ wide which appear in the gable walls and in the western wall should be sewn, larger ones should be rebuild. All walls should be dried and desalted.

The poor technical condition of wooden ceilings above the ground floor and upper floor, especially in the central part of the building, may threaten the safe operation of the building, and indicates the need to renovate the ceiling. In the central part, its immediate replacement is required, the remaining ceilings must be replaced during the planned renovation of the building. The vaults do not require reinforcement, they must be dried.

The roof does not threaten the safety of use; however, elements of the roof truss do not meet the requirements of ultimate limit states, it is recommended to secure, replace and strengthen the elements.

\section{CONCLUSIONS}

The city authorities of Kożuchów intend to restore the old attractiveness of the old town, plan to carry out the revitalisation of the Old Town in the near future. The scope of revitalisation activities results from the diagnosis of the technical condition of the degraded part of the city. The tenement house at 71 Maja Street is one of many buildings covered by the revitalisation programme. Renovation of the tenement house will not only provide an attractive offer on the real estate market, but will also improve the aesthetics of the city.

\section{REFERENCES}

1. Bucoń, R and Sobotka, A 2015. Decision-making model for choosing residential building repair variants. Journal of Civil Engineering and Management 21(7), 893-901.

2. Cibis, J and Nowogońska, B 2017. Diagnosis of transformation in architecture and construction of the housing stock in the years 1848-2013 in selected cities of Upper Silesia, WMCAUS Prague, Czech Republic, IOP Publishing, 2017, IOP Conf. Series: Materials Science and Engineering, Vol. 245, 052060.

3. Drozd, W and Kowalik, M 2020. Comparison of technical condition of multifamily residential buildings of various ages. Archives of Civil Engineering 66(1), 55-67. 
4. Eckert, W, Kochański, P and Nowogońska, B 2014. Kożuchów - Old Town center revitalization program, study design, stage Design Studio PAF, Zielona Gora [in Polish].

5. Fedorczak-Cisak, $M$ et al. 2019. Evaluation of the Criteria for Selecting Proposed Variants of Utility Functions in the Adaptation of Historic Regional Architecture. Sustainability 11(4), 1094.

6. Juszczyk, M and Leśniak, A 2019. Modelling Construction Site Cost Index Based on Neural Network Ensembles. Symmetry 11(3), 411.

7. Kafel, K, Leśniak, A and Zima, K 2019. Multicriteria comparative analysis of pillars strengthening of the historic building. Open Engineering 9(1), 1825.

8. Knyziak, P, Krentowski, J and Bieranowski, P 2017. Risks of the Durability of Large-Panel Buildings Elevations in Reference to the Conclusions from Technical Conditions Audits. MATEC Web of Conferences 2017, MATEC Web of Conferences, 117, 1-8.

9. Ksit, B and Gaczek, M 2018. Analytical meanders of selected systems for thermo-renovation of historical buildings, E3S Web of Conferences 49, 00062.

10. Malachowicz, E 1994. Maintenance and restoration of architectural and landscape teams, Publishing of University of Technology. Wroclaw [in Polish].

11. Nowogońska, B 2019. Performance characteristics of buildings in the assessment of revitalization needs. Civil and Environmental Engineering Reports 29(1), 119-127.

12. Nowogońska, B 2014. Model of the reliability prediction of masonry walls. Engineering Mechanics 2014 - 20th international conference Svratka, Czechy. Brno University of Technology, $456-459$.

13. Ostańska, A 2017. Evolution of Spaces between Buildings in Polish Mass Housing Estates in the Eyes of the Inhabitants. IOP Conf. Series: Materials Science and Engineering 245 (2017) 052044.

14. Radziszewska-Zielina, E, Kania, E and Śladowski, G 2018. Problems of the Selection of Construction Technology for Structures of Urban Aglomerations. Archives of Civil Engineering 64(1), 55-71.

15. Sztubecka, M, Skiba, M, Mrówczyńska, M and Bazan-Krzywoszańska, A 2020. An Innovative Decision Support System to Improve the Energy Efficiency of Buildings in Urban Areas. Remote Sensing, 12(2), 259.

16. Terlikowski, W 2018. Evaluation of the revitalization capacity of the historic building as an example of interdisciplinary diagnostics. VII Conference SOLINA Sustainable Development: Architecture - Building Construction E3S Web of Conferences 49, 00116. 